\author{
EliSA Moroni
}

\title{
BETWEEN ORALITY AND LITERACY: PARALLELISM AND REPETITION IN RUSSIAN FOLK EPICS AND THEIR CHALLENGE TO TRANSLATION
}

\begin{abstract}
Oral narratives such as Russian folk poetry have been relatively neglected by Translation studies, for the oral as such is hard to capture in writing without losing significant elements. In this paper we will focus on certain aspects and features of oral composition displayed as signs of the complex relationship between orality and literacy. In particular, we will present a series of problems involved in the translation of Russian oral epics in English and Italian. We will explore how the oral style and culture represented in the Russian folk poems (meant to be performed) are reflected in the translated texts eventually becoming estranging elements in the written system of the target language, and how translators cope with these elements. The encounter between these two semiotic systems - oral and written - in the translation produces an intricate combination of different stylistic norms, resulting in a transfer of oral devices into the translated written text. Translation then becomes a dimension where two different cultures meet, the alterity of the cultural other being maintained. Through an analysis of translations of Russian epics in Italian and English, we will try to find out how this transfer is realized in English and Italian, and how orality has influenced translation strategies.
\end{abstract}

\section{The transfer of orality in literacy}

Translating folklore may seem a paradoxical act in itself, as it implies the rendering of folkloric (oral) texts into another language by means of writing. As R. Jakobson $(2004,142)$ states, poetry is "by definition untranslatable. Only creative transposition is possible". If syntactic and morphological categories do not necessarily represent a major problem to the translation of prose, they are instead relevant to the translation of poetry, being primary elements of the poetic language (Jakobson 1980). This is even truer for folk poetry, where grammatical categories are not "merely formal" and become means of conveying meaning (Jakobson 2004, 142).

In this paper we will consider folklore through the prism of translation and explore the ways orality is translated within the means of literacy, through an analysis of several English and Italian translations of Russian oral epics. We will examine, in particular, the cultural and linguistic transfer of oral features occurring in the translation, which could be seen as a specific kind of "intersemiotic translation" (ibid., 139). A first semiotic transfer occurs in the source language through a transposition from performance to writing. "Oral traditional performances are collected, that is, caught and imprisoned in the anthropologist's or folklorist's game-bag via inscription on paper, acoustic media, or video media. ... Then come transcribing and editing, the initial stages in textual taxidermy, as scholars, now thankfully removed from the messiness of the original performance arena and comfortably ensconced in more clinical surroundings, render synthetic order unto the chaos of what once was a multi-dimensional, context-dependent experience" (Foley , 233). Translations of Russian folk epics are based on such kind of written text, where transcribers must have sometimes adapted the text they heard to the literary 
Russian language, but preserving at the same time oral devices. Thus, elements of orality, which is seen by scholars such as A. B. Lord (see Foley 1995, 4) as "the central distinguishing feature of this 'different' kind of 'literature'", may also be reflected in the translated texts. The cultural references present in oral epics sounded familiar to the audience listening to the performance; on the other hand, those narrations possessed stylistic and linguistic elements perceived as estranging by the listeners such as tautologies, repetitions, and epithets. Epithets are especially relevant in oral epic composition, since "they suggest the concrete, real quality of the object, serve the purpose of disclosing the theme, and carry a high semantic load" (Evgen'eva 1953, 139). ${ }^{1}$ Translators must deal with the same issue about this specific poetic style. Moreover, the elements of Russian folk culture (most of which belong to a now extinct cultural context) exert an additional estranging power in the translation. Hence, because the folk culture conveyed in the Russian epics is intricately embedded in its language and style, form and content should be at least taken into account. According to I. Muhawi (2006, 366), performance "sets up an interpretive frame that gives the receiver information needed for the correct interpretation of the message". In this view, verbal folk art is not a spontaneous form of speech, but, on the contrary, is built within a specific semiotic frame establishing its stylistic and compositional parameters. J. Bailey (1998, xxvii) indeed reminds us that "the traditional language of Russian folklore forms a distinctive and perceptible subcode of present-day Russian".

Style then becomes relevant to the translation of folklore. Our aim is to show how translations take into account the stylistic frame particular to Russian oral poetry, and how oral style and culture may have affected translators' choices, thus generating a unique style of translation. We will consider the role played in translation by devices of oral composition such as parallelism and repetition. These devices, used extensively in Russian folk poetry, do not have the same relevance in writing, where repetition especially is generally avoided. Moreover, "as a part of their oral presentation, singers use special tag lines to inform listeners who is talking to whom in speeches and dialogues. Although present-day readers may be annoyed by a repetition of the phrase 'hail to you', which frequently opens tag lines, in oral poetry these words function as a signal telling the audience that a speech is about to be addressed to someone" (ibid., xxvi). Repetition makes the written text appear somewhat odd.

Since the language of Russian epics consists of "archaic morphological, syntactic, and lexical items", differing "considerably from contemporary Russian speech and prose" (ibid., xxvii), we suggest that such oral texts may encourage a hybrid type of translation, resulting in a combination of standard, archaic and colloquial linguistic forms (although some translators may prefer a more standard register thus conforming to the target language norms). We will consider here the concept of translation advocated by Muhawi, based on H. Bhabha's (1994) idea about the role of cultural translation in "postmodern culture as a condition of hybridity" (Muhawi 2006, 370). This idea "does open out a reverse horizon in which interlingual translation is seen as a process from which the target text emerges as a hybrid construct, contaminated by the cultural values of its source, regardless how domesticating it may be".

\subsection{Folklore and translation}

This paper aims at opening up a number of issues relating to the translation of folk genres. The oral

\footnotetext{
1 "Ukazhivayut konkretnyy, zhivoy priznak predmeta, sluzhat raskrytiyu temy i nesut bol'shuyu smyslovuyu nagruzku". Unless otherwise noted, all translations of quotations from Russian references are my own. (Throughout the paper we will employ the system of the United States board on geographic names as a style for transliteration from Russian.)
} 
genres we are treating here, where an original text and also a true text as a complete and fixed form do not exist (see Bogatyrëv 1973; Chistov 2005; Finnegan 1980; Foley 1990; Lord 1960), are particularly challenging to translation for a number of reasons. "Unlike written literature, which for the most part exists only in a single fixed form once it has been printed, by its very nature oral literature in a living tradition constitutes an open-ended and continuous process that has no initial or final form. On the contrary, a given bylina may have been transcribed many times, but its variants, to a greater or lesser degree, always differ" (Bailey 1998, xlv). Russian folk epics, otherwise known as byliny, ${ }^{3}$ were relatively long texts that could be hardly known by heart. They "predominantly consist of a single episode and contain three to five hundred lines, although at times they may exceed a thousand" (ibid., xxviii). Singers indeed used formulas and formulaic fixed expressions to compose their songs. These formulas helped them to remember the basic plot of the story. Nonetheless, certain elements varied according to the singers' own inspiration and creativity. Variation and tradition indeed are two equally fundamental aspects of oral composition, and "the narration of a traditional genre of oral narrative, such as a folktale, legend or myth, is not a new invention but a performance, an individual iteration of a type that exists in free variation" (Muhawi 2006, 368). In their commentaries to byliny compilations, Russian collectors have frequently noticed that every time the same variant was sung, it looked as a different text as a result of the changes and new details introduced by narrators. Scholars such as B. N. Putilov $(1997,181)$ have widely studied the art of epic narrators, coming to the conclusion that Russian skaziteli, "narrators", represented quite a distinctive type of narrators among the known oral epic traditions. Translators should at least be aware of all these aspects of oral composition.

Although there is a number of works about the question of orality in translation, translation studies has mainly focused on written texts. As Muhawi (ibid., 367) writes, "In its almost exclusive concern with 'text', understood as stretches of written discourse, modern translation studies has tended to ignore the relevance of orality to its subject, though we do encounter the occasional reference to it in the literature". Moreover, only few of such works can be related to the field we are investigating (e.g., Bandia 1993, 2008; Barbin 2000; Muhawi 1999, 2006; Tymockzo 1995, 1999). Here indeed we deal with a specific form of verbal art differing from written genres meant to be read aloud or performed. "Theoretical reflection on the translation of folkloristic 'texts' can therefore span the gamut of the major issues animating translation studies today, linking the oral and the literate, the textual and the cultural" (ibid., 365). Furthermore, there are only few studies examining the translations of Russian folklore in western European languages: "Translations of Russian folklore in western European languages already have a long history, in need of scholarly attention" (Ivanova 1993, 313). ${ }^{5}$

\footnotetext{
${ }^{2}$ Here we particularly refer to Russian oral epics existing in form of several variants of single subjects. In this case a hypothetical original text from which all the variants of a subject come from can be only approximately reconstructed by scholars. As Bailey remarks (1998, xliii), "Russian epics nave no Urtext, and they are not static but undergo adaptation and reinterpretation as they pass through a succession of historical epochs".

3 "The word bylina is said to be derived from the past participial form (byl) of the verb byt, 'to be', and to signify 'that which has been', 'past occurrences"' (Chadwick 1936/1986, 3). These poems were epic tales (in verses) about heroes (bogatyr') set in medieval Russia, and reflecting Russian history between the tenth and the sixteenth centuries. The term bylina (plural byliny) was introduced as a scholarly designation of Russian folk epics in the 1830s by I. P. Sakharov, "who misunderstood the opening passage of the Slovo o polku Igoreve (Tale of Igor's Campaign), in which the word byliny occurs - probably with reference, not to poems, but to 'events of past times', 'true histories"' (ibid., 4).

${ }^{4}$ Singular skazitel', "narrator", from the verb skazat', "to say".

5 "Perevody russkogo fol'klora na zapadnoevropeyskie yazyki imeyut uzhe svoyu dovol'no davnyuyu istoriyu, trebuyushchuyu nauchnogo osmysleniya".
} 
Translating folk literature, orally performed and transmitted, is a complex task, involving the interaction of different semiotic systems. Russian epics, which once were oral performances and now are extinct and available in transcribed versions and sound recordings, represent a specific challenge for translation. ${ }^{6}$ Some scholars such as V. Ya. Propp (see Gatsak 1977, 182) are absolutely convinced of the impossibility of translating folk songs, while others believe in the translatability of folklore, but only if special means are being employed to convey the orality of folk literature. "Folk song is translatable, but it requires special means, not completely alike those successfully used in the translation of literary, individual, written poetry" (ibid.). ${ }^{7}$ According to V. M. Gatsak (ibid., 190), the translation of folk epics would require a different kind of approach from the translation of written poetry: it should not only render the content as an "amorphous, inventory transfer, as in linguistic and ethnographical translation", but also the poetic structure (ibid., 191). ${ }^{8}$

The language of Russian epics mixes together dialectal and archaic forms, often incomprehensible even to Russian native speakers. Moreover, much of the clarity and readability of the poems depends on the accuracy of the transcription. When in the texts appear obscure terms or passages it is not always easy to decipher whether these were mistakes of the compiler or unusual dialectal forms. Therefore, by examining translations of Russian folk epics we wish to raise questions that might be useful to the theory of translation, creating a connection between Translation and Folklore studies.

Russian epic poetry's language and style pose various problems for translation (Khrolenko 1992; Kidaysh-Pokrovskaya 1977; Tabakh'yan 1980) since they entail semantic and cultural spheres that are absent from literary and even colloquial speeches. As K. Mendoza (1993, x) states, "Translating oral poetry causes a dilemma far greater than with written literature". Russian epics employ a highly formulaic language based consistently on parallelism and repetition, which can hardly find adequate equivalents in other linguistic systems, since lexical and semantic units reflect symbols and metaphors deeply embedded in Russian traditional folk culture (Petenova 1985). "Such oral traditional forms are situated in part within a set of associations and expectations formally extrinsic but metonymically intrinsic to their experience as works of verbal art" (Foley 1995, xi). According to J. M. Foley (ibid., 29), in the context of oral composition words acquire a particular power and are "understood as signals that within the special domain of performance institutionally engage enormous spheres of traditional reference". For instance, in folk epics, an apparently simple word like belyy, "white", if matched with certain substantives, acquires semantic nuances that echo the traditional cultural dimension hidden behind the linguistic surface, where the colour white often designates beauty with reference to the Russian Christianized world (Khrolenko 1992). The symbolic connotations of certain Russian epic terms and epithets - especially those designating colours - do not always correspond in other languages such as Italian and English. For instance, the epic formula zelenoe vino, which could be literally translated as "green wine", can be referred to "vodka" or alternatively "liquor made of herbs": the true meaning of certain words is not always obvious. Furthermore, the singers themselves did not always

\footnotetext{
${ }^{6}$ We will not take into account sound recordings of Russian epics, since they do not serve the purpose of this paper. The translations considered here, indeed, are based upon transcriptions. Moreover, the passages examined belong to early collections (dating back to the nineteenth century), which could not recur to sound or video recordings. Music began to be included into compilations of byliny only in 1896.

7 "Narodnaya pesnya perevodima, odnako dlya etogo trebuyutsya osobye sredstva, ne sovsem te, chto uspeshno sluzhat pri perevode literaturnoy, individual'no-pis'mennoy poezii".

"Chisto amorfnym inventarnym pereneseniem, kak pri lingvisticheskom i etnograficheskom perevode".
} 
understand the meaning of some words, because certain terms and expressions were no more used in common day life. Those words and phrases were transmitted over generations of singers and belonged to an ancient oral poetic tradition, thus often losing their original meaning. "The semantic value of the epithet ... would serve as a nominal detail standing metonymically, or pars pro toto, for the character in all of his or her traditional complexity. Neither reducible to generic metrical fillers nor (by default) equivalent to literary, textual ways of naming, these formulas would be situated in the tradition" (Foley 1995, 5). Hence, they have the potential of becoming estranging elements in the translation.

There can be different ways of translating formulas such as zelenoe vino according to the meaning given to it by the translators and to the scope of the translation. For example, B. Meriggi (1974) translated it literally with vino verde, "green wine", thus avoiding any interpretation of the source text out of the literal meaning: this is a foreignizing strategy which may strengthen the estranging quality of the original. E. T. Saronne and K. F. Danil'chenko (1997), on the contrary, adapted the Russian term to the target culture, translating with vino novello, "new wine", thus domesticating the foreign element. This shows that the scope of the translation and the public it is addressed to determine the main strategies used by the translators. Meriggi's translation is probably directed to scholars and in particular specialists in Russian literature and culture, while Saronne and Danil'chenko's version is addressed to a wider public. ${ }^{9}$ In the Russian epics form and content are entirely and intricately interconnected, making these poems hardly translatable for those who strive to reproduce this primary element of the epic style. ${ }^{10}$ Consequently, an extremely fine correspondence of sound and sense - where this is the aim of the translator - may be hardly achievable, because of the inherent structural differences in syntax and phonology between the source and target languages.

Translating oral epics is a complex task especially from a cultural perspective, since oral narratives are "culturally saturated forms of verbal art" (Muhawi 2006, 365), and much of their essence and meaning is explained by the concrete situation in which they were originally performed (Finnegan 1980; Foley 1990; Lord 1960). However, the conditions established during the performance are inevitably lost when the poem is transcribed and then translated with the purpose of being read. Thus, the function of the source and target text radically changes. As P. F. Bandia (1993, 55) states, "The difficulties inherent in the translation process vary proportionately with the degree of distance between the languages and the cultures involved". Since there is often a great distance in terms of time and space between the source and the target text, it should be wondered what effect might be produced in the receiving culture in order to give back the essence of the original oral poem. Moreover, the medium used in oral epic differs from the one used in written literature. ${ }^{11}$ The former is based on direct communication of what is told and constant interaction between the singer and the audience, while the latter does not allow a direct connection between the author and his readers. "No aesthetic or cognitive distance exists between the collective oral palimpsest of tradition and the minds that compose, erase, and recompose that mental folio" (Foley 1987, 100). Unlike written literature, which can be read by anyone outside space and time limits, oral performances (and so the story narrated in the oral epic) live "in the continuous and continuing present of tradition" (ibid., 95).

\footnotetext{
${ }^{9}$ Here we use version as a synonym for translation.

${ }^{10}$ About the concept of translatability see Pym (2001, 273-276). By using the terms translatable and untranslatable we refer here to the great difficulty of translating oral epic poetry.

${ }^{11}$ For medium it is intended here the way communication is realized within the means of a literary or folkloric system. The term medium is employed with this meaning by Foley (1987).
} 
Folklore is characterized by the property of being iterated in numerous variants. As Muhawi (2006, 365) suggests, oral literature is "suspended between orality and literacy, without fixed form and capable of multiple realizations before manifesting itself as a performance that must be textualized to be translated". Writing materializes as a secondary stage, when folkloric texts are deprived of their primeval oral dimension. K. V. Chistov $(2005,52)$ remarks that folklore was set down on paper quite late. In addition, not all the performances could be recorded and retained: thus, transcribing oral texts may be described as a limited but necessary act, without which these texts would inevitably be lost and forgotten. In a Derridean sense translation would represent a sort of necessary survival of the original, which is in need of translation: "The original requires translation even if no translator is there, fit to respond to this injunction, which is at the same time demand and desire in the very structure of the original. This structure is the relation of life to sur-vival". The original, "the survivor, is itself in the process of transformation. ... It lives and lives on in mutation" (Derrida 1985/2002, 116, 117). Translation could be seen in this perspective as a successive act to transcription, necessary to the preservation of folk genres and the spread of their cultural meanings in other languages. Moreover, since folklore is capable of being iterated, its translation could become a sort of written variant in another semiotic system. According to Muhawi (2006, 368), "The fact that an item of folklore exists in variation - that is, it pre-exists individual performance - guarantees that it is repeatable, or, to use J. Derrida's term, "iterable". It would not exist if it were not iterable - capable of repetition but differently in each case". In this perspective, Muhawi (ibid.) sees this iterability as the quality allowing folk texts to survive living in different translations: "The Derridean concept of iterability has a dual significance in this context. It explains variation from a non-folkloristic perspective, putting it at the very core of how language functions, and it serves as a conceptual bridge connecting speech and writing. It thus also serves as a link between translation and folkloristics: if a speech genre is iterable in one language, there is a strong likelihood it will also be iterable in another".

Literacy is involved in the translations we have used: the English and Italian translations are written, with the intention of being read, and are therefore subject to the "requirement of readability" (ibid., 375). Their choices are conditioned by literary constraints imposed by the target cultures (see Toury 1995). "Every step in the translation process - from the selection of foreign texts to the implementation of translation strategies to the editing, reviewing, and reading of translations - is mediated by the diverse cultural values that circulate in the target language, always in some hierarchical order" (Venuti 2002, 308). However, translation might use the formal devices of orality to mark its diversity and specificity. "A translated text should be the site where a different culture emerges, where a reader gets a glimpse of a cultural other, and a resistancy, a translation strategy based on an aesthetic of discontinuity, can best preserve that difference, that otherness, by reminding the reader of the gains and losses in the translation process and the unbridgeable gaps between cultures" (ibid., 306). By virtue of what said above, the translations of Russian oral epics may become vehicles of estranging elements introduced from the source folk culture.

\subsection{Russian epic poems and their cultural specificity}

Russian folk epics are viewed in this paper from the perspective of translation. Different translations of these texts may allow to examine, albeit indirectly, changes occurring when converting oral texts into written form. Russian epos "probably originated from the tenth through the fourteenth centuries" in Kievan Rus' "but in the nineteenth and twentieth centuries" it "was discovered only 
among peasants living in the peripheries of Russia" (Bailey 1998, xvii, xxxvi). ${ }^{12}$ Byliny were narrative poems sung or recited mainly for entertainment by a single performer. They told stories about events or adventures occurring in the life of epic heroes. This kind of poetry, transmitted and performed among peasants, was still a living genre of Russian folklore until the second half of the twentieth century but had been dying out since the beginning of the century, because the circumstances that favoured its diffusion continually faded, and writing slowly substituted orality as a form of epic composition. The earliest collection of Russian epics dates back to the middle of the eighteenth century (but it was published in 1804), and is attributed to K. Danilov. However, folklorists and ethnographers started collecting folk songs more thoroughly from the nineteenth century on. In recent times epics have been found mainly in northern Russia (see Ivanova 2001) often mentioned as the "Iceland" of Russian epos (Putilov 1997, 178). ${ }^{13}$ Some of the most notorious byliny collections from the Russian North, on which are based the translations selected for this paper, are those compiled by P. N. Rybnikov (published from 1861 to 1867), and A. F. Gil'ferding (published in 1873). ${ }^{14}$ For the extensiveness of the material they comprise and the novelty they represented at the time of their publication, these collections are still considered of great value, even if they could not rely on the same technological means employed nowadays by folklorists and ethnographers. Moreover, these early collectors strived as much as possible to preserve the texts how they were performed by singers-narrators, usually not combining several variants such as to form a conflate text. ${ }^{15}$

Russian folklore played an important role in the shaping of a national literature, which often mirrored typical folk elements and characters. The dissemination of folklore in Russia was encouraged by the fact that wide layers of Russian society were illiterate, and among those communities folklore could be easily cultivated. Moreover, written literature was under the Church controls right up until the eighteenth century, while folk poetry and narratives - by means of their oral transmission - could more easily escape from censorship (Jakobson 1945). "Until recently written literature" in Russia "was an exotic product, with a very limited range of circulation", and oral literature "was the only form of literature or of intellectual activity known to the overwhelming majority of the population" (Chadwick 1936/1986, xiv). According to H. M. and N. K. Chadwick (ibid.), Russian folk songs may be regarded as a counterpart "of the whole written literature of the western peoples". Only through oral transmission in areas far from religious control could the secular themes that shaped nineteenth and twentieth century Russian literature develop. Folklore thus is certainly relevant to the Russian cultural polysystem for historical reasons, but in the target systems Russian folk texts may acquire a marginal or peripheral position. ${ }^{16}$ It is by virtue of this marginality that they may encourage diversions from the

\footnotetext{
${ }^{12}$ Rus' was the old name for ancient Russia, which "extended from near the Baltic Sea in the north to the steppe bordering on the Black Sea in the south, and from the Carpathian Mountains in the west almost to the Volga River in the east. [...] The Kievan state was founded in the second half of the ninth century" (Bailey 1998, xvii).

${ }^{13}$ Epics have been also recorded along the Volga River (to the east of Moscow), in the Don region, in the Urals and Siberia. For a thorough description of the main theories on the geographic distribution of byliny, see Bailey (1998, xxxvi-xxxvii) and Ivanova (2001).

${ }^{14}$ See references in this paper.

${ }^{15}$ Actually Rybnikov did not transcribe the epic poems from a sung performance but from a "spoken paraphrase". This method had its limits, since "the rhythm of the verbal text fell apart during a spoken retelling": Gil'ferding thus "realised that accurate texts could be obtained only from a sung performance" (Bailey 1998, xvi-xvii).

16 "The term polysystem refers to the aggregate of literary forms (from innovative verse to children's literature) that exist in any given culture" (Gentzler 2001, 169). Polysystem theory has been outlined by I. Even-Zohar in the 1970s.
} 
writing norms of the target culture, through the introduction of oral epic devices and stylistic norms into translation such as the paratactic structure of sentences. "In oral poetry there are few 'descriptive', 'analytical' forms typical to written literature" (Evgen'eva 1953, 134). ${ }^{17}$ Thus the use of paratactic constructions in the translated written text may create a sense of estrangement. Translation might become then a place for writing and oral to encounter originating an intermediate cultural universe, where differences are maintained instead of being removed (see Derrida 1985/2002).

The target languages and cultures have a multitude of genres, registers, and styles into which various kinds of oral text might be translated (e.g., west European ballads such as English ballad poetry), but true analogies to the Russian oral epics cannot be really found in modern western oral literatures (Chadwick 1936/1986, xiii). ${ }^{18}$ Thus, for the purposes of this paper we are concentrating mainly on the source texts, i.e., the Russian originals. What is more, the translations examined here do not explicitly recur to specific folk genres of the receiving cultures: it could be observed that such strategy seems to be disregarded by the translators, although at a less conscious level they might have drawn on their native oral tradition. The use of folk patterns of the target cultures would nonetheless lead to a completely different type of translation implying a prevalence of domesticating strategies, which is not what these translators, at least in their overt intentions, seem to aim at.

Oral literature, especially in a relatively recent past, has been often considered less relevant than written literature in scholarly discourse. "With their attention to texts, scholars often went on to assume, often without reflection, that oral verbalization was essentially the same as the written verbalization they normally dealt with, and that oral art forms were to all intents and purposes simply texts ... The impression grew that ... oral art forms were essentially unskillful and not worth serious study" (Ong 1982, 10). Thus, folklore has been often underestimated in literary studies. "Yet, despite the oral roots of all verbalization, the scientific and literary study of language and literature has for centuries, until quite recent years, shied away from orality. Texts have clamored for attention so peremptorily that oral creations have tended to be regarded generally as variants of written productions or, if not this, as beneath serious scholarly attention" (ibid., 8). A comparative analysis of the Russian source texts and their Italian and English translations, i.e. three languages belonging to different cultures, might reveal how the target culture's parameters together with the norms of the source culture are mirrored in the translations.

\subsection{Oral devices and epic language}

The language of folklore mainly corresponds to dialect, but it also has specific characteristics that distinguish it from dialect in its communicative function (Bogatyrëv 1973, 108). Furthermore, archaic linguistic forms often occur in oral poetry: for example, in Russian byliny archaic words were often archaisms in regard to literary language, but they were still used in dialect, even in everyday language (Evgen'eva 1953, 131). A typical trait of Russian epics (and oral poetry in general) is the use of suffixes such as diminutives, usually related to heroes and the objects belonging to them; on the contrary, suffixes with a negative or pejorative connotation are always associated to enemies and their objects. Moreover, heroes are often addressed with names such as Dobrynyushka, Il'yushen'ka, Aleshen'ka and so on, which are diminutives of Dobrynya, Il'ya, Alesha (ibid., 134-135). All these

\footnotetext{
17 “V ustnoy poezii ochen' malo 'opisatel'nykh', 'analiticheskikh' form, stol' zhe kharakternyh dlya pis'mennoy literatury”.

${ }^{18}$ See Chadwick (1936/1986, xii) for a general description of English balladry.
} 
aspects of the epics may represent a problem for translators, especially when in the target language there is no similar use of such suffixes.

The lexical and semantic specificity of the folkloric word is regarded by A. T. Khrolenko (1992, 18) as one of the characteristics that render folk poetry far more complex in terms of translation than written literature. The most ancient meanings of the epic as a genre lie in its poetic devices: it is in epithets and recurrent formulas that metaphors, symbols, and archaic concepts and views are preserved and conveyed. In Russian epic poetry epithets play an essential function, especially within its rhythmical framework, since they answer precise poetic needs and metric conventions. "Standing formulae and stock motifs and situations are very common. ... Common actions and events, especially such as occur frequently in daily life, tend to be described in identical terms" (Chadwick 1936/1986, 72). The extensive use oral poetry makes of certain devices, such as parallelism and repetition, has often been regarded as the first and most evident distinction between oral and written poetry. Repetition is, indeed, "one of the most characteristic features of the byliny. It occurs with especial frequency in speeches. Very commonly we find long passages repeated with hardly any variation. ... Such repetitions are often used with considerable skill to hold the imagination in check and prepare for the effect of a new announcement - the climax. Hence they commonly occur before important statements or in situations of emotional stress" (ibid., 73). By means of parallelism and repetition, successive lines of a poem are associated to express similar or contrasting ideas. In addition, "the repetition of long passages is no doubt due to the poet's desire to make his story last as long as possible, coupled with a knowledge that such devices have a certain cumulative effect" (ibid., 74). Scholars have identified different types of parallelism; for instance, A. N. Veselovskiy $(2008,126)$ describes a particular kind of parallelism which he defines as psychological, originating from ancient animistic views pervading poetry with parallels and juxtapositions between animal and human life. Another kind of parallelism derives from the psychological, which Veselovskiy calls rhythmic, because it is mainly based on musical and rhythmic congruencies and similarities. Jakobson $(1966,424)$, on the other hand, maintains that oral poetry is built on pervasive parallelism, located at every linguistic level, where grammatical structures become a means to convey poetical meanings. Since parallelism and repetition are essential features in folk poetry and convey the specificity of the oral style (Tedlock 1972, 119), we argue, they might have implications for translation, depending on the translator's approach and purpose, and on what he will decide to maintain: form or content or both.

\section{Translations of Russian epics}

In this section we will examine English and Italian translations of Russian folk epics to verify where oral devices have, in effect, influenced strategies and choices, causing deviations from the norms of the target languages, and where, instead, there are deviations from the source text.

There are several translated versions of byliny both in English and Italian, but in this paper we will examine only three of them, those seemingly more alike in terms of form and intentions. ${ }^{20}$ It seems that these translations share a certain kind of approach towards folk genres: they do not try, at least overtly,

\footnotetext{
${ }^{19}$ Russian folk epics have a particular verse form, also determined by the musical accompaniment. There are different varieties of folk meter, but the most common one is a "tonic measure with three stressed positions in the line and with changeable unstressed intervals between them whose number can vary from one to three" (Gasparov 1996, 21).

${ }^{20}$ See Chadwick $(1936 / 1986,4-5)$ and T. G. Ivanova (1993, 313-323) for a thorough commentary about western studies of Russian folk epics and translations of byliny in western European languages.
} 
to adapt the foreign text to the target culture, but instead strive to keep close to it. This may be the result of specific socio-cultural views on oral literature. Ivanova (1993) has identified a certain European tradition in the translation of Russian byliny: the first translations in European languages date back to the nineteenth century, reflecting the growing interest towards that genre within European scholarship. "Translations of byliny in western European languages dating back to the first half of the century played an important role in acquainting other peoples with Russian epos. However, at times the first translations turned out to be only free transpositions, and sometimes simply author's inventions on the themes of Russian epos. They did not adequately reflect byliny's artistic side, and did not even render accurately the songs' content" (ibid., 314). ${ }^{21}$ One of the first English translations of byliny (made by W. R. Ralston in 1872) comprised only two subjects, one of which was a paraphrase. This work certainly represented an important contribution to the knowledge of Russian folk songs in the English speaking countries, but the translation, according to its contemporaries, was not enough accurate. Ralston's anthology of Russian folk poetry was followed by another English translation, I. F. Hapgood's The epic songs of Russia (appeared in 1886 and published again in 1915), which "consists of translations of conflate texts of a selection of byliny" (Chadwick 1936/1986, 5). The main principle used in this translation is called by the author herself eclecticism: as she found not relevant translating all the variants of a subject, she then aggregated (by means of paraphrase) various parts of different variants in one text (Ivanova 1993, 316). Moreover, according to Ivanova (ibid., 316-317), Hapgood seemed not aware of all the poetic and stylistic traits of Russian epics: "As it is known, repetitions of different kinds are one of the essential principles in the poetics of Russian epos: trebling episodes, the whole system of loci communes and formulas. The numerous clichés permeating the whole artistic essence of byliny do not impoverish their poetics, but, on the contrary, constitute their fundamental trait. When she was translating repeating commonplaces and phrases, Hapgood thought she should have employed corresponding English expressions. However, the translator often renders repeating formulas in different and new ways". ${ }^{22}$ Sentences and entire lines couplets in byliny are repeated identically in several passages. For instance, in the epic Alesha Popovich i Tugarin Zmey (from the collection by K. Danilov) the same expressions repeat twice without any change. ${ }^{23}$ However, Hapgood $(1886,93,94)$ does not render these repetitions. The first time she translates as follows: "Ho there, courteous lord, Prince Vladimir! What lout is this that is come to the court, what untutored fool? For he sitteth not honourably at thy table", and then: "Courteous Lord Vladimir! What boor and unpolished dullard is this that sitteth here?" (See Ivanova 1993, 319). In spite of its drawbacks, Hapgood's translation played an essential role in spreading Russian folklore, in particularly epos, in England and

\footnotetext{
21 “Perevody bylin na zapadnoevropeyskie yazyki, zdelannye v pervoy polovine stoletiya, sygrali svoyu vazhnuyu rol' v dele znakomstva drugikh narodov s russkim epicheskim tvorchestvom. Odnako podchas pervye perevody okazyvalis' vsego lish' vol'nymi perelozheniyami, a inogda i prosto avtorskimi fantaziyami na temu russkogo eposa; oni ne tol'ko ne otrazhali adekvatno originalu hudozhestvennuyu storonu bylin, no zachastuyu i ne peredavali tochno soderzhanie pesen”.

22 "Kak izvestno, odnoy iz osnov poetiki russkogo eposa yavlyayutsya razlichnogo roda povtory: utroenie epizodov, tselaya sistema loci communes i formul. Mnogochislennye klishe, pronizyvayushchie vsyu khudozhestvennuyu tkan' bylin, ne obedinyayut ikh poetiku, a, naprotiv, sostavlyayut vazhneyshuyu eë osobennost'. Pri perevode povtoryayushchikhsya mest $\mathrm{i}$ fraz Hapgood, kazalos' by, dolzhna byla kazhdyy raz ispol'zovat' odni i te zhe sootvetstvuyushchie angliyskie vyrazheniya. Odnako ochen' chasto perevodchitsa povtoryayushchiesya formuly peredaët kazhdyy raz po-novomu".

${ }^{23}$ The original Russian passage quoted by Ivanova $(1993,319)$ repeats twice in the text, sounding as follows: "Goy esi ty, laskovyy sudar' Vladimer-knyaz'! / Chto u tebya za bolvan prishel, / Chto za durak neotesonoy? / Nechestno u knyazya za stolom sidit" (in an idiomatic translation it would read as follows: "Hail to you, tender sir Vladimir-prince! / What at your [place] a dolt came, / What a fool unpolished? / Not honorably by the prince at the table [he] sits").
} 
in the United States. New English translations of byliny appeared soon after and only one of them, Chadwick's (published in 1932), introduced other principles than those employed by Hapgood: the author rendered the epic lines literally by maintaining repetitions and fixed formulas, but did not try to give back their rhythmical structure. The most recent English translation of Russian epos is Bailey's (1998): the translator here takes into account not only the content but also the poetic form and metric patterns of the original poems.

According to Ivanova (ibid., 320), the European interest in Russian folklore, raised in the first half of the twentieth century, was probably linked to the critical historical events taking place at that time. In Italy the first Italian translations of Russian byliny and folk songs appeared in the same period marking a growing interest in Russian oral literature. The earliest Italian translation, D. Ciampoli's anthology of Russian epics (1911), generally keeps the form of the original, although in some cases the author tends to use poetic literary register. Except for this translation, the two other versions in Italian, Meriggi's (1974) and Saronne and Danil'chenko's (1997), try to maintain the poetic structure of the original and do not combine variants of the same subject together. The three translations analysed in this paper are all scholarly works, although Saronne and Danil'chenko seem to address not only to scholars. It is interesting to notice that while the two Italian translations report the Russian originals as parallel text, the English only gives the translated version. It may also be seen as part of the translator's strategy: the translation has to be read as an independent text. Unlike the Italian translators, Bailey clearly states his intentions in the introduction to his anthology: "The purpose of this anthology is to convey what V. M. Gatsak (1977) calls a "folkloristic translation", that is, all types of repetition and parallelism have been retained insofar as is feasible. ... Some aspects of colloquial English, especially contractions, have been used when appropriate. ... The basic purpose has been to provide as readable a translation as possible while preserving as many folklore features of the original Russian as the English language will permit" (Bailey 1998, xlv-xlvi).

One should first state that all the three translations examined here try to recreate a specific folkloric style, by maintaining in Russian those words not having direct equivalents in other languages, for example realiya of Russian folklore, ${ }^{24}$ folk culture, history and reality, which are usually untranslatable. Bailey (1998, xlvi) confirms this choice in the preface of his anthology: "terms for Old Russian weights and measures as well as specifically Russian words (bogatyr and druzhina) have been retained so as to preserve a certain cultural atmosphere". In all three anthologies substantives such as terem, bogatyr', druzhina, lapti, pud (to mention only a few $)^{25}$ are left in Russian. This may be delineated as a foreignizing strategy to maintain the difference of the other. Since folk poetry belongs to an ancient tradition connected to the deepest roots of one culture, such untranslatable words abound. It is interesting to notice how Saronne and Danil'chenko $(1997,272)$ keep transliterated even the word tsar', although an Italian equivalent exists. In the commentary they say that their translation is addressed to an audience of non-specialists. Thus, their attempt to use a foreignizing strategy in the translation is manifested in the creation of a hybrid style, where several and contrasting registers (i.e. russified Italian, "ordinary" literary Italian, Russian and Italian oral epic style) are mixed together to recreate the complexity of the Russian oral epic vocabulary. A foreignizing method is applied and shared to some extent by all three translators. Another common strategy is to keep the order of the lines

\footnotetext{
${ }^{24}$ Realiya (English realia) designates real life artifacts and other elements specific to one culture.

${ }^{25}$ These words designate respectively: (tower-) room or high lord's house; epic hero; military force; shoes made of lime (tree) bark; old Russian unit of measurement.
} 
as it appears in the original: "The identity of the lines is maintained to preserve a sense of poetry" (Bailey 1998, xlv). Bailey has certainly tried to maintain oral devices and fixed formulas as much as possible, but at the same time he mostly keeps English standard language. Saronne and Danil'chenko, on the other hand, explain why they have used archaic words and phrases, but they do not mention their approach toward formulas and epithets. Meriggi makes an apt introduction to the meanings and history of byliny, but he does not hint about his translation strategy, which can only be deduced from the text.

As said above, all these three translations are scholarly works, although Saronne and Danil'chenko seem to address a wider public. For this reason they eventually try to produce a literary translation to capture the attention of the reader. The two other versions are instead more literal and keep close to the Russian original, retaining its alterity. Anyway, the estranging element of orality is somewhat displayed in each text giving the style of the translations a certain peculiarity.

\subsection{Epithets and formulas}

Through the following analysis of the translations of byliny, we wish to show how the aforementioned constant (although present in variable measure) estranging element - represented by orality - may possibly link all these translations together. No matter how domesticating or foreignizing the strategies employed might be, the translations would nevertheless show some significant deviation from the target language norms. This is especially due to the fact that these translators often seem to strive to keep close to the form of the original. As mentioned above, Russian folk poetry being highly formulaic, form becomes sometimes even more relevant than content. We should add that this is a quality of all poetry: "In poetry there is obviously a greater focus of attention upon formal elements than one normally finds in prose. Not that content is necessarily sacrificed in translation of a poem, but the content is necessarily constricted into certain formal moulds. Only rarely can one reproduce both content and form in a translation, and hence in general the form is usually sacrificed for the sake of the content" (Nida 2004, 154). However, the translators of byliny seem to opt more frequently for formal correspondence than dynamic equivalence. Some of them adopt (in certain passages) an analogous to what E. Nida (ibid., 155) calls "gloss translation", attempting "to reproduce as literally and meaningfully as possible the form and content of the original".

Firstly, we shall see how translators have tried to render formulas and epithets, and then how they translated parallelism and repetition at a morphological, syntactic and semantic level. The examples given in Table 1 are the most common and recurrent formulas in Russian byliny. They are followed by their English and Italian translations. Since in Russian formulas often remain unchanged, translators, where possible, have strived to render them almost in the same way, but sometimes they employ synonyms to serve prosodic norms of their own language (as we will see below). All the English extracts given in Table 1 are by Bailey (1998), while the Italian passages are by Meriggi (1974) and Saronne and Danil'chenko (1997). ${ }^{26}$ Formulas shown here are taken from different byliny, but we basically refer to the source texts as given in the translations. Bailey does not include the Russian original in his anthology; thus, in the passages cited from his translation we do not insert the Russian text. Our aim though is to examine the translations comparing their choices and strategies; not always having the Russian text should not be a substantial problem for the purpose of the analysis.

\footnotetext{
${ }^{26}$ All the phrases in quotation marks shown in the tables from now on are idiomatic translations from Russian and Italian. All the idiomatic translations from the originals shown in the text will be given in notes.
} 
Table 1: Epithets and formulas

\begin{tabular}{|c|c|c|c|c|}
\hline & Russian & Bailey & Meriggi & $\begin{array}{l}\text { Saronne and } \\
\text { Danil' chenko }\end{array}$ \\
\hline (1) & $\begin{array}{l}\text { Beloe litso } \\
\text { 'white face' }\end{array}$ & White face & $\begin{array}{l}\text { Bianco volto } \\
\text { 'white face' }\end{array}$ & $\begin{array}{l}\text { Volto bello } \\
\text { 'beautiful face' }\end{array}$ \\
\hline (2) & $\begin{array}{l}\text { Chistoe pole } \\
\text { 'clean field' }\end{array}$ & Open field & $\begin{array}{l}\text { Campo aperto } \\
\text { 'open field' }\end{array}$ & $\begin{array}{l}\text { Sgombra pianura } \\
\text { 'empty plain' }\end{array}$ \\
\hline (3) & $\begin{array}{l}\text { Dobryy kon' } \\
\text { 'good horse' }\end{array}$ & Good steed & $\begin{array}{l}\text { Bravo cavallo } \\
\text { 'good horse' }\end{array}$ & $\begin{array}{l}\text { Buon destriero } \\
\text { 'good steed' }\end{array}$ \\
\hline (4) & $\begin{array}{l}\text { Buynaya golova } \\
\text { 'impetuous head' }\end{array}$ & Reckless head & $\begin{array}{l}\text { Impetuoso capo } \\
\text { 'impetuous head' }\end{array}$ & $\begin{array}{l}\text { Focosa testa } \\
\text { 'fiery head' }\end{array}$ \\
\hline (5) & $\begin{array}{l}\text { Belyy svet } \\
\text { 'white world' }\end{array}$ & White wild world & $\begin{array}{l}\text { Bianco mondo } \\
\text { 'white world' }\end{array}$ & $\begin{array}{l}\text { Mondo bello } \\
\text { 'beautiful world' }\end{array}$ \\
\hline (7) & $\begin{array}{l}\text { Dobryy molodets } \\
\text { 'good young man' }\end{array}$ & Young man & $\begin{array}{l}\text { Bravo giovane } \\
\text { 'good young man' }\end{array}$ & $\begin{array}{l}\text { Bravo prode } \\
\text { 'good brave man' }\end{array}$ \\
\hline (10) & $\begin{array}{l}\text { Beloe telo } \\
\text { 'white body' }\end{array}$ & White body & $\begin{array}{l}\text { Bianco corpo } \\
\text { 'white body' }\end{array}$ & $\begin{array}{l}\text { Bel corpo } \\
\text { 'beautiful body' }\end{array}$ \\
\hline (11) & $\begin{array}{l}\text { Palaty belokamenny } \\
\text { 'white stone palace' }\end{array}$ & White-stone palace & $\begin{array}{l}\text { Palazzo di bianca } \\
\text { pietra } \\
\text { 'palace of white } \\
\text { stone' }\end{array}$ & $\begin{array}{l}\text { Marmoreo palazzo } \\
\text { 'marble palace' }\end{array}$ \\
\hline (12) & $\begin{array}{l}\text { Strelochka kalënaya } \\
\text { 'tempered arrow' }\end{array}$ & Tempered arrow & $\begin{array}{l}\text { Freccia rovente } \\
\text { 'red-hot arrow' }\end{array}$ & $\begin{array}{l}\text { Freccia temprata } \\
\text { 'tempered arrow' }\end{array}$ \\
\hline (13) & $\begin{array}{l}\text { Kosyashchatoe } \\
\text { okoshko } \\
\text { 'window with jambs' }\end{array}$ & $\begin{array}{l}\text { Window with a wooden } \\
\text { frame }\end{array}$ & $\begin{array}{l}\text { Finestra con gli } \\
\text { stipiti } \\
\text { 'window with jambs' }\end{array}$ & $\begin{array}{l}\text { Finestra di fine fattura } \\
\text { 'Finely worked window' }\end{array}$ \\
\hline
\end{tabular}

While Bailey has strived to be consistent with his translation of fixed formulas, not changing them and thus maintaining the style of Russian epos (although sometimes formulas can be varied within a poem, these are little variations, due mainly to prosodic reasons), Saronne and Danil'chenko often replace them, even within the same text, according to the nuances they want to give those specific lines or passages. In fact, in their texts they do not always translate examples (2), (4), (7), (11), and (12) as shown in Table 1, but employ different options: for instance, (2) is sometimes translated as campo aperto, "open field"; (4) as calda testa, "hot head"; (7) as baldo prode, "bold brave man"; (11) as palazzo bianco-marmoreo, "white-marble palace", or marmoree stanze, "marble rooms"; (12) as freccia rovente, "red-hot arrow", or freccia d'acciaio temprato, "tempered steel arrow". This shows a clear intention to maintain a control over the text: the translator thus becomes visible (in the sense advocated by L. Venuti), inserting estranging elements or deviating somewhat from the norms of the 
target language. In the introduction of the anthology there is a clear statement about the approach adopted in the translation: "In our translation we have sometimes stretched the style, by introducing lexical and syntactic archaisms or structures which are intentionally disrespectful to the current norm" (Saronne and Danil'chenko 1997, 73). ${ }^{27}$ This method allows the use of words, expressions and phrases which are a combination of different registers, leading sometimes to a stretching of Italian syntax and style, as a result of a precise translation choice. The English translation generally appears much more homogeneous than its Italian counterparts, especially if compared with Saronne and Danil'chenko's version. ${ }^{28}$ Bailey always tries to use the same formulas and epithets to imitate the epic style of the original, as he writes in the introduction: "Since the language of the bylina, as would be expected in an orally composed epic, abounds in fixed or nearly fixed phrases and expressions, a deliberate attempt has been made to translate such elements consistently" (Bailey 1998, xlvi). Although he retains some features of orality and certain colloquial expressions, he mainly employs a standard literary language, which distances its translation from the register of the Russian text. On the one hand this homogeneity is maybe an attempt to stress and reproduce the repetitiveness of the epic style, introducing anyway an element of estrangement maintaining the alterity of the original. On the other hand this homogeneity may be also due to the syntactic and morphological differences of English and Russian. The heterogeneity of an English translation would stem from different lexico-grammatical features: whereas Russian has more to play with at the grammatical end of the scale, English has more at the lexical end, but Bailey chooses to 'simplify' and standardize the English of his translation. As Jakobson says (2004, 141-142): "In poetry above all, the grammatical categories carry a high semantic import. In these conditions, the question of translation becomes much more entangled and controversial. ... Syntactic and morphological categories, roots, and affixes, phonemes and their components (distinctive features) - in short, any constituents of the verbal code - are confronted, juxtaposed, brought into contiguous relation according to the principle of similarity and contrast and carry their own autonomous signification".

The intentions of the translators are also different: Bailey states that he wishes to reproduce the style of the epic as far as possible, while Saronne and Danil'chenko declare their irreverence to the current norms of the target language, but in the end they all aim at retaining the foreign elements. The skopoi of their translations determine their choices and strategies. If we look at the examples in Table 1, we notice that Meriggi and Bailey employ in most cases more literal translations, whereas Saronne and Danil'chenko often opt for different choices to render the symbolic or metaphoric connotations expressed in the original. For instance, Meriggi and Bailey both keep the epithet belyy, "white", in its primary meaning designating the colour white, as in the examples (1), (5), (10), (11), although in (5) Bailey adds the adjective "wild", thus adding an extra-connotation. Belyy svet certainly does not refer to a generic white world; in the epic white alludes to the world of the living, as opposed to the world of the dead. This formula is a common phrase in Russian, and it is used to indicate the "whole world". Bailey tries to render this connotation with the inclusion of "wild", but at the same time keeping "white" perhaps to retain the exoticism conveyed by a more literal translation, where white represents an element of difference. Saronne and Danil'chenko, however, translate belyy as "beautiful", especially

\footnotetext{
27 "Nella nostra traduzione abbiamo qua e là forzato lo stile, introducendo a volte arcaismi lessicali e sintattici o strutture volutamente irrispettose della norma corrente".

${ }^{28}$ Version here is used as a synonym of translation and does not have any extra connotation (see also footnote 10 , section 1.1).
} 
where it is used to refer to the hero or to the Russian world: choosing a less literal translation, they manage to convey the positive overtones of the original epithet. The same applies to most of the formulas expressing the idea of beauty, as in examples (10) and (13). The latter is produced by Saronne and Danil'chenko using a freer translation; in effect the epithet kosyashchatoe, "with jambs", alludes to the fine work of the window's jambs. ${ }^{29}$ Meriggi and Bailey again prefer a more literal translation. In (2) and (3) Saronne and Danil'chenko choose words, sgombra, "empty", and destriero, "steed", that belong to an epic literary register, thus introducing an element of distance from the source text. Destriero, especially, suggests Old Italian epic literature. Bailey also refers to an Old English epic style by using "steed" in (3), which is a non-neutral word for "horse". Both horse and steed thus are nonneutral, but in different ways, because the ways in which they are embedded in their respective lexicons - phonologically as well as grammatically and semantically - are different.

\subsection{Repetition as mark of orality in translation}

In this section we will analyse a few passages from the English and Italian translations of Russian folk epics, to highlight repetition, according to the functions it covers in the texts. Our aim is to determine, on the one hand, how this feature is reflected in the translations, conditioning their stylistic choices and becoming a vehicle of estrangement. On the other hand, we intend to investigate the role the target language norms have played in the translations, dictating specific modes of expression. Anyway, the translators of byliny obviously strive to render repetitions as much as possible, following in most cases an approach oriented towards formal equivalence. This choice is possibly related to certain cultural considerations about what should be the right representation of the source texts. For example, Nida (2004, 154) sees cultural implications beneath the choice of prose for English translations of Homer's epic poetry: "Homer's epic poetry reproduced in English poetic form usually seems to us antique and queer - with nothing of the liveliness and spontaneity characteristic of Homer's style. One reason is that we are not accustomed to having stories told to us in poetic form. In our western European tradition such epics are related in prose. For this reason E. V. Rieu chose prose rather than poetry as the more appropriate medium by which to render The Iliad and The Odyssey". These considerations may be also applied to the reception of the Russian epics within the English and Italian cultures: since a direct analogous of such poems cannot be found in the receptor cultures, the translators, choosing a poetic translation, might introduce new elements and patterns deriving from the source culture. The original texts considered here for comparison with their translations belong basically to two byliny collections, compiled by Rybnikov and Gil'ferding in the nineteenth century (see section 1.2 of this paper). For instance, the bylina Sadko was recorded by Rybnikov from the singer A. P. Sorokin in Olonets Province in 1860; the variants of the bylina Dobrynya and the dragon were recorded by Gil'ferding respectively from P. L. Kalinin in Povenets District of Olonets Province in 1871, and A. E. Chukov in Kizhi (Olonets Province); the bylina Dobrynya and Marinka was recorded by Gil'ferding from the singer I. Eremeev in Olonets Province in $1871 .^{30}$

Table 2 shows repetition in three consequent lines of an epic. The Russian text ${ }^{31}$ is followed by the

\footnotetext{
${ }^{29}$ The peasants' houses were often decorated with wooden inlays, which can be found even nowadays especially in the Russian North.

${ }^{30}$ For Dobrynya and the dragon Saronne and Danil'chenko employ a variant (originally comprised in Gil'ferding's collection) reedited by V. I. Kalugin in 1987.

${ }^{31}$ Bylina Sadko (Rybnikov 1861-67/1990, vol. 2, no. 135).
} 
English (Bailey 1998, 296) and the Italian translations (Meriggi 1974, 262). ${ }^{32}$

Table 2: Imitation of repetition

\begin{tabular}{|l|l|l|l|}
\hline & Russian & Bailey & Meriggi \\
\hline (1) & $\begin{array}{l}\text { Sadka den' ne zovut na } \\
\text { pochesten pir } \\
\text { 'Sadko one day [they] don't call } \\
\text { to the honourable feast' }\end{array}$ & $\begin{array}{l}\text { The first day they didn't invite } \\
\text { Sadko to a feast of honour }\end{array}$ & $\begin{array}{l}\text { Un giorno non lo chiamano al nobile } \\
\text { banchetto } \\
\text { 'One day they don't call him to the noble } \\
\text { feast' }\end{array}$ \\
\hline (2) & $\begin{array}{l}\text { Drugoy ne zovut na pochesten } \\
\text { pir } \\
\text { '[The] second day [they] don't } \\
\text { call to the honourable feast' }\end{array}$ & $\begin{array}{l}\text { The second they didn't invite } \\
\text { him to a feast of honour }\end{array}$ & $\begin{array}{l}\text { Un altro giorno non lo chiamano al nobile } \\
\text { banchetto } \\
\text { 'Another day they don't call him to the } \\
\text { noble feast' }\end{array}$ \\
\hline (3) & $\begin{array}{l}\text { Itretiy ne zovut na pochesten } \\
\text { pir } \\
\text { 'And third [day they] don't call } \\
\text { to the honourable feast' }\end{array}$ & $\begin{array}{l}\text { And the third they didn't invite } \\
\text { him to a feast of honour }\end{array}$ & $\begin{array}{l}\text { Il terzo giorno non lo chiamano al nobile } \\
\text { banchetto } \\
\text { 'The third day they don't call him to the } \\
\text { noble feast' }\end{array}$ \\
\hline
\end{tabular}

In Table 2 we see that ne zovut na pochesten pir, "they don't call to a feast of honour", is repeated in all three lines in Russian, while den', "day", in example (1), drugoy, "second", in example (2), and tretiy, "third", in example (3) are parallel by virtue of both position and meaning in the line. In both the English and Italian translations the structure of parallelism and repetition and the words' order are preserved. Parallelism in the original is built on the opposition of den', drugoy, and tretiy, where the latter two underline den', which does not need to be repeated in Russian. Bailey reproduces literally the arrangement of the Russian sentences, recreating the same parallel effect; Meriggi also imitates repetition adding the word giorno, "day", in examples (2) and (3).

Because of its morphological structure, Russian allows a freer disposition of the words in the lines; whereas Italian and especially English must submit to the constraints of a less flexible syntax. This is particularly manifest in the English translation, where the organization of the sentences is generally more rigid. The parallel effect, however, is attained, and repetitions are kept as they appear in Russian, even if this means stretching the syntax of the target language. What is revealed through the performance is indeed not always feasible in English or Italian, but both translators attempt to retain this specificity of oral poetic discourse. Viewing this phenomenon in G. Toury's terms (1995, 88-89), we may observe that oral style is transferred in the target texts, resulting in a transposition of oral techniques and devices into the literary language employed in the translations. This transposition of linguistic elements develops into a cultural transfer, insofar as those features of orality carry the cultural otherness of the Russian folk epics with all its power of breaking the conventional norms of the receiving system. In their efforts in preserving parallelism and repetition, translators thus create a set of lines which may sound unfamiliar and monotonous to the target readers (possibly expecting something

\footnotetext{
${ }^{32}$ For more details and information about the Russian texts see the introductions to the anthologies (Bailey 1998; Meriggi 1974; Saronne and Danil'chenko 1997).
} 
different from a written text). The effect produced on contemporary Russian readers may be analogous, in that common readers read a transcription, which is different from a performance but also different from a written text meant to be read. We cannot ascertain whether this was the effect the translators had in mind, but Bailey (1998, xvli) at least asserts that he has deliberately strived to imitate the style of the folk epic: "All types of repetition and parallelism have been retained insofar as is feasible". Bailey in effect employs repetition as a consistent pattern in various ways: he iterates words, sentences, entire lines and episodes as a direct imitation of the Russian epic line. We can observe this expedient in the following lines: "Then they put the oaken checkers / On the board, on the maple board. / Then they played with oaken checkers / On the maple board" (Bailey 1998, 159), where the reiteration of sentences and words clearly resembles the techniques of Russian folk poetry. The same kind of repetition is introduced again a few lines further on the same text: "For twelve years, for thirteen years, / For thirteen and a half years. / Then they played with oaken checkers / On the maple board" (ibid., 159). These are only a few examples of the extensive use Bailey makes of repetition as a mark of orality, but they enable us to identify the main translator's method based on the reproduction of the epic style. The constant recurrence of repeated units within and between the lines may produce a sense of strangeness on the reader. A similar effect is created by Meriggi, who often iterates several lines couplets within the same poem. In the following example distributed throughout different stretches of one passage of the text (Meriggi 1974, 70): "He beats the snake on the only tail, / the snake now prays, he bows", is repeated again a few lines further on, without any change. ${ }^{33}$ This is a technique which may seem odd to a reader accustomed to written literature: it is an imitation of the folkloric style.

Saronne and Danil'chenko (1997, 207), too, employ repetition consistently rendering the oral style of the Russian original: "To go into those burrows - those dragon's burrows" ${ }^{34}$ In this line quelle tane, "those burrows", appears twice, producing the effect of a refrain. The same happens in the following example (ibid., 191): "Far far - in the open field", ${ }^{35}$ where the repetition of lontano lontano, "far far", helps to place the text in a dimension reminiscent of the atmosphere of fairy-tales.

\subsection{Parallelisms}

In this section we will examine Italian translations, giving examples which contain various types of parallelism, in order to analyse the different ways translators have rendered this technique. The text in Russian $^{36}$ conveys not only semantic, but also syntactic and phonological parallelism. We shall see how this twofold interconnection between the elements of the sentences and the lines is realized and transformed in the translations.

Table 3: From morphological to semantic parallelism

\begin{tabular}{|l|l|l|l|}
\hline & Russian & Meriggi & Saronne and Danil'chenko \\
\hline (1) & $\begin{array}{l}\text { Da y ko tym goram da } k \\
\text { Sorochinskiim } \\
\text { 'And towards the Sorochin }\end{array}$ & $\begin{array}{l}\text { Verso i monti di Sorochin } \\
\text { 'Towards the Sorochin mountains' }\end{array}$ & $\begin{array}{l}\text { Verso quei monti di Sorochin } \\
\text { gloriosi } \\
\text { 'Towards those glorious }\end{array}$ \\
\hline
\end{tabular}

\footnotetext{
33 "Batte il serpente nell'unica coda, / prega adesso il serpente, fa un inchino".

34 "Di andare in quelle tane - quelle tane di drago".

35 "Lontano lontano - nella sgombra pianura".

${ }^{36}$ Bylina Dobrynya and the dragon (Gil'ferding 1873, no. 148).
} 


\begin{tabular}{|l|l|l|l|}
\hline & mountains' & & Sorochin mountains' \\
\hline (2) & $\begin{array}{l}\text { Da y ko tym noram da ko zmeinyem } \\
\text { 'And to those burrows and to } \\
\text { serpent [burrows]' }\end{array}$ & $\begin{array}{l}\text { Là dove sono covi di serpi } \\
\text { 'There where there are snakes' } \\
\text { dens' }\end{array}$ & $\begin{array}{l}\text { Verso quelle tane - quelle tane } \\
\text { di drago } \\
\text { 'Towards those burrows - } \\
\text { those dragon's burrows' }\end{array}$ \\
\hline (3) & $\begin{array}{l}\text { Eshche den' za den' kak budto } \\
\text { dozhd' dozhdit } \\
\text { 'Again day by day as if rain rains' }\end{array}$ & $\begin{array}{l}\text { Giorno dopo giorno - come } \\
\text { pioggia che cade } \\
\text { 'Day by day - like rain that falls' }\end{array}$ & $\begin{array}{l}\text { E un giorno dopo l'altro come } \\
\text { pioggia che non cessa } \\
\text { 'And day by day like rain that } \\
\text { doesn't stop' }\end{array}$ \\
\hline (4) & $\begin{array}{l}\text { Da y nedeli za nedeley kak reka } \\
\text { bezhit } \\
\text { 'And week after week as river runs' }\end{array}$ & $\begin{array}{l}\text { Settimana dopo settimana - come } \\
\text { fiume che scorre } \\
\text { 'Week after week - like river that } \\
\text { flows' }\end{array}$ & $\begin{array}{l}\text { Settimane e settimane come } \\
\text { fiume che non resta } \\
\text { 'Week by week like river that } \\
\text { doesn't stay' }\end{array}$ \\
\hline
\end{tabular}

As we can see in Table 3, the first two examples in Russian are shaped on parallelism at both the phonological, syntactic and semantic levels, where goram, "to mountains", and Sorochinskiim, "of Sorochin" in example (1) are parallel respectively to noram, "to burrows", and zmeinyem, "of dragons", in example (2), all in the dative case. G-oram and n-oram are phonologically and semantically parallel. All the other elements are repeated. Examples (3) and (4) are also built on syntactic, phonological and semantic parallelism, where den' za den', "day by day", and dozhd' dozhdit, "rain rains", in example (3) are parallel to nedeli za nedeley, "week after week", and reka bezhit, "river runs", in example (4). This complex morphological structure cannot be retained in the translations. However, translators have tried to render the semantic parallelism in different ways. Both Meriggi $(1974,243)$ and Saronne and Danil'chenko $(1997,193)$ preserve the opposition between the two parallel elements, pioggia, "rain", and fiume, "river", in the last two examples, and Saronne and Danil'chenko manage to establish a kind of phonological parallelism between cessa, "stops", and resta, "stays". In examples (1) and (2), they create a connection between monti, "mountains", and tane, "burrows", adding repetition in quelle tane - quelle tane di drago, "those burrows - those dragons' burrows", which does not appear in the Russian text. Thus, they use a poetic device of folkloric composition even where it is not found in the original text. A similar strategy we have seen in Bailey's translation (see section 2.1), thus showing the influence such patterns have on the translators' choices and methods.

Table 4: Imitation of parallelism

\begin{tabular}{|l|l|l|l|}
\hline & Russian & Meriggi & Saronne and Danil'chenko \\
\hline (1) & $\begin{array}{l}\text { To on den' edet po krasnomu } \\
\text { solnyshku } \\
\text { 'Then he [in the] day goes after } \\
\text { the beautiful sun' }\end{array}$ & $\begin{array}{l}\text { Di giorno cavalca sotto il rosso } \\
\text { solicello } \\
\text { 'In the day he gallops under the } \\
\text { little red sun' }\end{array}$ & $\begin{array}{l}\text { Di giorno cavalca inseguendo il } \\
\text { sole } \\
\text { 'In the day he gallops chasing } \\
\text { the sun' }\end{array}$ \\
\hline (2) & $\begin{array}{l}\text { Da on v noch' ekhal po svetlomu } \\
\text { mesyatsu } \\
\text { 'And he in [the] night goes after }\end{array}$ & $\begin{array}{l}\text { Di notte cavalcava sotto la luna } \\
\text { lucente } \\
\text { 'In the night he galloped under the }\end{array}$ & $\begin{array}{l}\text { Di notte inseguiva la lucente } \\
\text { luna } \\
\text { 'In the night he chased the }\end{array}$ \\
\hline
\end{tabular}




\begin{tabular}{|l|l|l|l|}
\hline & the bright moon' & shining moon’ & shining moon' \\
\hline
\end{tabular}

In Table 4 the translators both reproduce semantic parallelism of the Russian lines, ${ }^{37}$ and at a first glance their translations appear quite similar. However, there are some slight differences. Meriggi's $(1974,243)$ version is more literal, closer to the original, imitating even syntactic parallelism and retaining, in example (1), the diminutive solnyshko, "little sun", in solicello, "little sun". Saronne and Danil' chenko's version $(1997,193)$ is more poetic and closer to the canons of Italian literary language using adjectives as lucente, "shining", which belongs to a higher poetic register than svetlyy, "bright". They exclude, in example (1), the fixed epithet krasnoe, "beautiful", or "red", usually associated to the sun in Russian oral epics, and in example (2) the repetition of the verb ekhat', "to go".

Table 5: Tautology in parallelism: violation of written style

\begin{tabular}{|l|l|l|l|}
\hline & Russian & Meriggi & Saronne and Danil'chenko \\
\hline (1) & $\begin{array}{l}\text { Da y ne dozhd' dozhzhit da y to } \\
\text { ne grom gromit } \\
\text { 'And [it is] not rain rains and } \\
\text { not thunder thunders' }\end{array}$ & $\begin{array}{l}\text { Non pioggia che cada, non tuono } \\
\text { che tuoni } \\
\text { 'Not rain that falls, not thunder that } \\
\text { thunders' }\end{array}$ & $\begin{array}{l}\text { Non è la pioggia che piove, non } \\
\text { il tuono che tuona } \\
\text { 'It is not rain that rains, not } \\
\text { thunder that thunders' }\end{array}$ \\
\hline (2) & $\begin{array}{l}\text { A y ne grom gromit, da shum } \\
\text { velik idët } \\
\text { 'And [it is] not thunder } \\
\text { thunders, and noise big goes' }\end{array}$ & $\begin{array}{l}\text { Non tuono che tuoni, è un grande } \\
\text { rumore che viene } \\
\text { 'Not thunder that thunders, it is a } \\
\text { big noise that comes' }\end{array}$ & $\begin{array}{l}\text { Non è il tuono che tuona, ma c'è } \\
\text { un grande fragore } \\
\text { 'It is not thunder that thunders, } \\
\text { but there's a big rumble' }\end{array}$ \\
\hline
\end{tabular}

In Table 5 we can observe the use of tautology, present in the Russian text, ${ }^{38}$ in both translations. Tautology, in some ways a form of phonological and semantic repetition, is employed to stress the parallelism between the two phrases dozhd' dozhzhit, "rain rains", and grom gromit, "thunder thunders", in example (1), and grom gromit again in example (2). While Saronne and Danil'chenko $(1997,197)$ retain all three features, thus recreating also the parallel effect of the original, Meriggi $(1974,245)$ reproduces the second and the third, but not the first repetition, which is changed into pioggia che cada, "rain that falls". In this case both translations are quite literal: by introducing the tautologies, the Italian stylistic norms of writing are challenged and violated.

Table 6: Distortions of literalness

\begin{tabular}{|l|l|l|l|}
\hline & Russian & Bailey & Meriggi \\
\hline$(1)$ & $\begin{array}{l}\text { Vstaët on po utryshku } \\
\text { ranëkhon'ko } \\
\text { 'He gets up early in the morning' }\end{array}$ & He got up very early in the morning & $\begin{array}{l}\text { Si alza all'alba, di buon mattino } \\
\text { 'He gets up at dawn, early in the } \\
\text { morning' }\end{array}$ \\
\hline
\end{tabular}

\footnotetext{
${ }^{37}$ Bylina Dobrynya and the dragon (Gil'ferding 1873, no. 148)

${ }^{38}$ Bylina Dobrynya and the dragon (ibid.)
} 


\begin{tabular}{|l|l|l|l|}
\hline (2) & $\begin{array}{l}\text { Umyvaetsya on da belëkhon'ko } \\
\text { 'He washes himself to [become } \\
\text { white' }\end{array}$ & He washed himself very thoroughly & $\begin{array}{l}\text { Si lava, egli, bianco bianco } \\
\text { 'He washes himself, white } \\
\text { white' }\end{array}$ \\
\hline (3) & $\begin{array}{l}\text { Snaryazhaetsya on } \\
\text { khoroshokhon'ko } \\
\text { 'He equips himself very well' }\end{array}$ & $\begin{array}{l}\text { He dressed himself very } \\
\text { handsomely }\end{array}$ & $\begin{array}{l}\text { Ben bene egli si equipaggia } \\
\text { 'Very well he equips himself' }\end{array}$ \\
\hline
\end{tabular}

The Russian examples ${ }^{39}$ shown in Table 6 present a series of parallel lines, describing three hero's consequent actions, which prepare him for his departure to the open field: he gets up early, washes himself, and dresses or equips himself. This is a central passage representing the beginning of the epic, and it is shaped on parallelism, both phonological (the ending of the words ranë-khon'ko, "very early", belë-khon'ko, "to very white", and khorosho-khon'ko, "very well", coincides), and semantic. Bailey $(1998,101)$ keeps as always a clear and intelligible style; he interprets the formulas of the parallelism avoiding a strict literalism. However, Meriggi $(1974,102)$ employs a more literal method of translation, causing distortion of meaning: for instance, in example (2), bianco bianco, "white white", corresponds to a literal meaning of the Russian belëkhon'ko, but it is not a true equivalent. However, Meriggi's choice shows again the encounter of orality and literacy in translation.

\subsection{Folkloric register as an estranging element}

In this section we will show, through a few examples from different translations, how translators have been influenced by the register and language of the folk epics. This happens more often in the Italian than in the English texts, as we can see in Table 7 below.

Table 7: Colloquialisms and folkloric phrases

\begin{tabular}{|l|l|l|l|}
\hline & Russian & Bailey & Meriggi \\
\hline (1) & $\begin{array}{l}\text { Dam tri rybiny zoloty per'ya } \\
\text { 'I'll give three fishes [with] } \\
\text { golden fins' }\end{array}$ & $\begin{array}{l}\text { I'll give you three fishes with } \\
\text { golden fins }\end{array}$ & $\begin{array}{l}\text { Ti darò tre pescioni dalle squame d'oro } \\
\text { 'I'll give you three big fishes with } \\
\text { golden scales' }\end{array}$ \\
\hline (2) & $\begin{array}{l}\text { Kak znayu chudo chudnoe v } \\
\text { Ilmen'-ozere } \\
\text { 'As I know [a] wonderful } \\
\text { wonder in Ilmen' Lake' }\end{array}$ & $\begin{array}{l}\text { I know a wondrous wonder } \\
\text { in Ilmen Lake }\end{array}$ & $\begin{array}{l}\text { So di un portento portentoso nel lago } \\
\text { Ilmen' } \\
\text { 'I know a wonderful wonder in Ilmen' } \\
\text { Lake' }\end{array}$ \\
\hline
\end{tabular}

In example 1 of Table 7 Meriggi $(1974,265)^{40}$ employs pescioni, "big fishes", to render into Italian the Russian word rybiny, designating a big fish in a colloquial register. In this way, the translator adopts the oral style of the original, conveying the specificity of the folkloric language and creating a sense of distance from the literary style. Anyway, although they are often employed in colloquial speech, diminutives in Italian are not frequent as they are in Russian. Moreover, words like pescioni

\footnotetext{
${ }^{39}$ Bylina Dobrynya and Marinka (Gil'ferding 1950, vol. 2, no. 163)

${ }^{40}$ Bylina Sadko (Rybnikov 1990, vol. 2, no. 135)
} 
here appear even queerer, since in his translation Meriggi mainly uses a standardized Italian. Bailey's (1998, 297-298) translation, on the contrary, does not portray the colloquial nuance expressed in rybiny, remaining on a quite neutral register. As Bailey (ibid., xlvi) states in his introduction, "It has not been possible to convey the overtones of the hypocoristics (affectionates, diminutives, pejoratives, and augmentatives) that abound in the idiom of Russian epics because direct English equivalents do not exist".

In example (2) we can notice an attempt to render literally the epic style in both translations, in that they retain the tautological formula chudo chudnoe, "wonderful wonder", thus stretching the conventions of the literary language and introducing an expression that can be at once acknowledged as foreign.

In the next tables (8 and 9) we will see examples in English and Italian referring to different variants of the same bylina, ${ }^{41}$ which nevertheless have much in common. For each table we chose only one line which is very similar in the two original variants. ${ }^{42}$

Table 8: Diminutives

\begin{tabular}{|l|l|l|}
\hline Bailey & Meriggi & Saronne and Danil'chenko \\
\hline $\begin{array}{l}\text { He trampled all the little baby } \\
\text { dragons }\end{array}$ & $\begin{array}{l}\text { Hai pestato } \text { i piccoli serpentelli } \\
\text { 'You trampled the little little } \\
\text { snakes' }\end{array}$ & $\begin{array}{l}\text { Tutti } \text { i dragoncelli hai calpestato } \\
\text { 'You trampled all the little } \\
\text { dragons' }\end{array}$ \\
\hline
\end{tabular}

The examples in Table 8 show how the three translators have rendered the diminutives of the Russian epic. English does not allow the use of the diminutives as Russian does: as we can see, Bailey $(1998,91)$ tries to render the diminutive of the given line by adding the word "baby" to "dragons", while in Russian it is conveyed by one word, zmeenyshi, "little dragons" (the dragons' babies, dialect form). In Italian, on the contrary, diminutives are used in colloquial speech, thus allowing a closer translation. Meriggi $(1974,259)$ uses the phrase piccoli serpentelli, "little little snakes", diminutive for serpente, "snake", while Saronne and Danil'chenko (1997, 213) dragoncelli, "little dragons", diminutive for drago, "dragon": both, indeed, manage to recreate a colloquial register in the target text, introducing an element of the Russian folkloric speech. However, Meriggi has misinterpreted the word zmeenyshi, which means "dragons" and not "snakes". This was possible since the words zmey, "dragon", and zmeya, "snake", are similar, having the same root. Moreover, the declension of these words is often obscure in the Russian epic texts, thus generating confusion in translation. This last statement could open a series of interesting issues regarding textual criticism of Russian oral epics and folklore in general, which cannot be discussed here. We shall just mention that the nature of the transcriptions, often the product of several phases of reediting, is a problematic question. As we have

\footnotetext{
${ }^{41}$ English translation: Dobrynya and the dragon (Gil'ferding 1949, vol. 1, no. 5). Italian translations: Dobrynya and the dragon (Gil'ferding 1873, no. 148).

${ }^{42}$ In the variant translated by Bailey Russian original reads as follows (Gil'ferding 1949, vol. 1, no. 5): "Stal toptat' da malen'kikh zmienyshev" ("[He] began to trample little [little] dragons"), while in the variant translated by Meriggi and Saronne and Danil'chenko (Gil'ferding 1873, no. 148): "Potoptal ty malyikh zmeënyshev" ("trampled you little [little] dragons").
} 
seen in the previous sections, although they are still considered relevant to the history of Russian folklore, old transcriptions are not always reliable, because they could not use recordings in those days, and were based on the ethnographer's understanding and choices: many elements could be misunderstood and omitted. "It became apparent that collecting methods and editorial practices affect the texts and that mistakes, distortions, and changes might occur at all stages in the existence of a text, from its transcription in the field to its final realization in print. One of the main temptations has involved the urge to 'improve' a text by standardizing the language in accordance with the norms of the contemporary standard language" (Bailey 1998, xliv). This aspect of course has consequences on translation, since translators can only rely on printed texts which are only copies of copies of the oral performances. Thus, there are often unclear passages offering to different interpretations.

Table 9: Emotionalism in folk language

\begin{tabular}{|l|l|l|}
\hline Bailey & Meriggi & Saronne - Danil'čenko \\
\hline $\begin{array}{l}\text { Don't go bathing in the mother } \\
\text { Puchay River }\end{array}$ & $\begin{array}{l}\text { Al fiume Puchay, gloriosa madrina } \\
\text { 'To the Puchay river, glorious } \\
\text { godmother' }\end{array}$ & $\begin{array}{l}\text { Verso il glorioso fiume-madre di } \\
\text { Puchay 'To the glorious river-mother of } \\
\text { Puchay' }\end{array}$ \\
\hline
\end{tabular}

The passage in Table 9 shows an example of the emotionalism conveyed by the folkloric language, ${ }^{43}$ expressed not only through diminutives, but also through nouns of address such as matushka, ${ }^{44}$ literally "little mother", an archaism mainly employed in poetry, nineteenth century literature and folklore as a diminutive of mat', "mother", used to express affection and respect towards the addressed object. The matushka of the example is used to address the river "as a token of respect" (Bailey 1998, 84), marking its special function within the plot.

The Puchay River of the example is ferocious and angry, almost acquiring human traits: it is described as "an ominous place ..., marking the boundary between two worlds" (ibid., 82). The mythological feminine representation of the river is directly linked to the grammatical gender of the word reka, "river". As Jakobson states, "Even such a category as grammatical gender ... plays a great role in the mythological attitudes of a speech community. In Russian the feminine cannot designate a male person, nor the masculine specify a female. Ways of personifying or metaphorically interpreting inanimate nouns are prompted by their gender" (Jakobson 2004, 142).

All three translators retain the noun of address to convey a sense of respect towards the river, but the results are quite different. Bailey $(1998,84)$ employs the word mother as a literal translation of matushka, but the archaic poetic register of the original is lost. Meriggi (1974, 241), instead, uses madrina, "godmother", thus altering the meaning of the word, but is able to retain the respectful connotation of matushka reproducing the higher register of the Russian text emphasized by the epithet

\footnotetext{
${ }^{43}$ Bailey's variant of Dobrynya and the dragon is from Gil'ferding (1949, vol. 1, no. 5): 'Ne kuplis'-ko ty vo matushke Puchay-reki" ("don't bath you in mother Puchay-river"); Meriggi and Saronne and Danil'chenko's variant is from Gil'ferding (1873, no. 148): "Ko toy slavnoyu ko matushki k Puchay-reki" ("To the glorious to mother Puchay-river").

${ }^{44}$ Matushka is also used as a respectful form to call the priest's wife, or in dialects to call women in general (Ushakov 1938, 163).
} 
glorious. Saronne and Danil'chenko $(1997,191)$ have deliberately tied the noun of address madre, "mother", to fiume, "river", thus stressing the significance of the Puchay River, which, according to some scholars, would represent a tributary of the Dnepr River, where possibly took place the christening of ancient Russians (ibid., 280). However, in the source text there is an impediment to accurate translation into Italian. In Russian, reka, "river", is feminine and so the formula matushka reka, "mother river", appears completely logical and normal. In Italian, the word fiume, "river", is masculine and madre, "mother", is feminine. The combination of the two words, madre fiume, is thus the result of a strategy consciously used by the translators, but inevitably leads to a distortion of the grammatical sense of the Italian syntax. That said, this distortion is part of the translation strategy encouraged by the folkloric language, and it is only one of the aspects defining the estranging potential that Russian folklore may exert in translation.

\subsection{Discussion and conclusions}

In the English and Italian translations of byliny analysed in the previous paragraphs we have identified the use of different strategies underlining the influence of the folkloric style on the target texts, and some traits that characterize the style of each translator. The analysis has shown that these translations all somewhat strive to keep close to the original maintaining features and patterns of orality in the written translated text. We have seen that fixed formulas, parallelisms and repetitions, features of the folkloric language and register - such as archaisms, diminutives and nouns of address - are retained as much as possible even when this may produce a queer effect in reading. The primary scope of these translations is therefore rendering the epic style of the original texts: this can be connected to a certain tradition of byliny translations in European languages (see section 2). However, there are maybe other - less evident - scopes guiding the translators.

Apparently the aim is the search for formal correspondence, rendering verb by verb, word by word, and sentence by sentence, maintaining the order of the lines: the general tendency of these translations seems to be the use of literalism, even if at various degrees. Thus the introduction of oral poetic devices in writing encourages various types of deviation and shifts from the norms of the literary language. On the other hand there are also some attempts to produce a translation that is readable and fluent, above all in English, as it is clearly asserted by the author himself. For instance, Bailey mainly employs a literary language, standardizing and sometimes normalizing the frequent changes of register typical to the oral epic. This shows that after all translators, despite their overt intentions of representing the original text without adapting it to the receptor culture, somehow "polish" this text by removing such oral elements as variation or phonological repetition. All the three translations are meant to be read, and this must have influenced, even if only at an unconscious level, translators' choices and strategies.

Meriggi's and Saronne and Danil'chenko's versions result estranging in different ways: the former employs literalism more consistently, often breaking target language norms, while the latter is more poetic, but this sense of poetry is created by mixing together different styles and registers (archaic, colloquial and literary), and stretching grammatical categories like gender, which comes from an attempt to transpose Russian epic language into translation. Meriggi, who was himself a scholar expert in Slavonic cultures, addressed his translation to scholars and specialists who were probably supposed to know Russian, and might have therefore better accepted deviations from the target language norms, since readability was clearly not the primary scope of his translation. Saronne and Danil'chenko are also scholars, but they do not confine their text to a scholarly audience. This is clear in the attempt of rendering their translation more poetic through the use of formulas recalling Italian written epic poetry. 
All these translations are based on transcribed versions of byliny, which are already "polished" texts even though they retain dialect, and deviations from the grammatical and morphological norms of standard Russian language. Transcriptions may thus seem queer to contemporary Russian readers, as do byliny translations to the target readers. A shift from the source texts, indeed, already occurs in the replacement of dialect with standard literary language, although translators might even use dialect to convey Russian epic language, but this choice would imply a different approach. Saronne and Danil'chenko employ sometimes such kind of approach, introducing colloquial or regional expressions. However, even when the translator tries to stay closer to the target language, the effect may be sometimes queer. It may be argued that translators of folk epics tend to produce estranging translations, although at different degrees. Orality is already present in the Russian original as an estranging element, transferred from oral performances into the written text. Then by means of his own language the translator will interpret and represent this element according to the translation and literary norms of the receptor culture. Translations such as Hapgood's paraphrase (which could be better described as an adaptation $)^{45}$ tend to exclude orality to create a narrative text which may be more acceptable to the target culture. But this may also reflect socio-cultural views on folk poetry: in Hapgood's cultural environment and time it was maybe not that relevant to produce an ethnographic translation (that is, close to the original), rendering adequately features of orality. The main aim of the earliest translations, indeed, was to render the content of the epics.

The three translations examined here, on the contrary, share the intention of giving their audience an insight into the structure of Russian byliny, and they all somewhat retain orality (see Nida 2004, 154). Meriggi's and Bailey's translations are both literal, even though in the former the estranging element is predominant. In Meriggi's version an estranging power is exerted by both oral features and literalism, which distances the text from its reader. Saronne and Danil'chenko instead retain the heterogeneous style of the original thus recreating the same estranging effect.

Since folklore is a repository of the deepest roots of a culture, being the best representative of its alterity, its translation may have the potential of introducing new estranging elements into another culture. We may suggest that in all the three translations analysed in this paper, indeed, the difference of the cultural other is maintained by preserving, to some extent, the orality of the folk texts. At the same time, though, this orality is transformed acquiring a new aspect. Seen in a Derridean perspective, the translation of folklore may become a place where oral and written meet creating a new dimension, which is neither only oral nor only written, but a combination of the two in difference. ${ }^{46}$ In this dimension oral would exert an influence on writing, and vice versa. Moreover, only in such dimension folk works could keep on living: this new existence would guarantee their life outside time and space.

All these considerations lead us to acknowledge the potential of oral poetry to influence literary modes of expression, by introducing oral devices into the means of literacy. Being marginal to the polysystem of target cultures, folklore may represent a point of rupture with conventional norms of translation. Hence, we argue, it may be also relevant to the theory of translation, encouraging further discussions on the meaning and the practice of translation itself.

\footnotetext{
${ }^{45}$ See section 2 of this paper.

${ }^{46}$ See the concept of equivalence in difference by Jakobson $(2004,139)$.
} 


\section{References}

Bailey, J. 1998. An anthology of Russian folk epics. New York and London: M.E. Sharpe.

Baker, M., eds. 1998/2001. Routledge Encyclopedia of Translation studies. London and New York: Routledge.

Bandia, P. F. 1993. Translation as Culture Transfer: Evidence from African Creative Writing. In TTR : traduction, terminologie, rédaction, 6 (2): 55-78.

- P. F. 2008. Translation as reparation. Writing and translation in postcolonial Africa. Manchester: St. Jerome Publishing.

Barbin, F. 2000. Les récits populaires du Devon: problems de method et de traduction. In Oralité et traduction, ed. Michel Ballard, 293-319. Lille: Artois Presses Université.

Bhabha, H. 1994. The location of culture. London and New York: Routledge.

Bogatyrëv, P. G. 1973. Yazyk fol'klora. Voprosy yazykoznanya, no. 5: 100-116.

Chadwick, H. M., and N. K. 1936/1986. The growth of literature, vol. 2. Cambridge: Cambridge University Press.

Chistov, K. V. 2005. Fol'klor, tekst, traditsija. Moscow: O.G.I.

Ciampoli, D. 1911. Poesia russa: byline, canti storici, Canto d'Igor. Lanciano: Carabba Editore.

Dal', V. 1863-1966/1978-1980. Tolkovyy slovar' zhivogo velikorusskogo yazyka. 4 vols. Repr. Moscow: Russkiy yazyk.

Derrida, J. 1985/2002. De tours de Babel. In Acts of religion, ed. Gil Anidjar, 102-133. London and New York: Routledge.

Evgen'eva, A. P. 1953. Vvedenie. In Russkoe narodnoe poeticheskoe tvorchestvo. Ocherki po istorii russkogo narodnogo tvorchestva X - nachala XVIII vekov., ed. V. P. Adrianova-Perets, 118-140. Moscow and Leningrad: AN SSSR.

Finnegan, R. 1980. Oral poetry: its nature, significance and social context. Bloomington and Indianapolis: Indiana University Press.

Foley, J. M. 1987. Man, Muse, and Story: Psychohistorical Patterns in Oral Epic Poetry. Oral Tradition, 2 (1): 91-107. 
1990. Traditional oral epic. The Odyssey, Beowulf, and the Serbo-Croatian return song. Berkeley, Los Angeles, Oxford: University of California Press.

. 1995. The singer of tales in performance. Bloomington and Indianapolis: Indiana University Press.

. 2005. From Oral Performance to Paper-Text to Cyber-Edition. Oral Tradition, 20 (2): 233-263.

Gasparov, M. L. 1996. A history of European versification. Transl. and ed. G. S. Smith. Oxford: Clarendon Press.

Gatsak, V. M. 1977. Problema fol'kloristicheskogo perevoda eposa. In Fol'klor. Izdanie eposa, ed. A. A. Petrosyan, 182-216. Moscow: Nauka.

Gentzler, E. 2001. Poetics of translation. In Routledge Encyclopedia of Translation studies, ed. M. Baker, 167-170. London and New York: Routledge.

Gil'ferding, A. F. 1873/1949-51. Onezhskie byliny, zapisannye A. F. Gil'ferdingom letom 1871 goda. 4th ed., 3 vol. Moscow and Leningrad: AN SSSR.

Hapgood, I. F. The epic songs of Russia. New York: C. Scribner's sons, 1886.

Ivanova, T. G. 1993. Russkie byliny v angliyskikh perevodakh. In Russkiy fol'klor. Mezhetnicheskie fol'klornye svyazi, vol. 27, 313-323. St. Petersburg: Nauka.

—. 2001. "Malye” ochagi severnorusskoy bylinnoy traditsii: issledovaniya i teksty. St. Petersburg: Dmitriy Bulanin.

Jakobson, R. 1945. Russian Fairy Tales. New York.

—. 1966. Grammatical parallelism and its Russian facet. Language 42 (2): 399-429. http://www.jstor.org/stable/411699.

—. 1980. A postscript to the discussion on grammar of poetry. Diacritics 10 (1): 22-35. http://www.jstor.org/stable/465038.

- 2004. On linguistic aspects of translation. In The translation studies reader, ed. Lawrence Venuti, 138-143. London and New York: Routledge.

Kalugin, V. I. 1987. Byliny. Moscow: Sovremennik.

Khrolenko, A. T. 1992. Semantika fol'klornogo slova. Voronezh: Izdatel'stvo Voronezhskogo universiteta. 
Kidaysh-Pokrovskaya, N. V. 1977. Perevod tyurkoyazychnykh epicheskikh pamyatnikov v akademicheskoy serii. In Fol'klor. Izdanie eposa, 128-166. Moscow: Nauka.

Lord, A. B. 1960. The singer of tales. Cambridge: Harvard University Press.

Mendoza, K. 1993. Talking books, ethnopoetics, translation, text. Columbia: Camden House.

Meriggi, B. 1974. Le byline: canti popolari russi. Milano: Accademia.

Muhawi, I. 1999. On translating Palestinian folk tales: comparative stylistics and the semiotics of genre. In Arabic grammar and linguistics, ed. Y. Suleiman, 222-245. Richmond: Curzon Press.

- 2006. Towards a folkloristic theory of translation. In Translating others, ed. Theo Hermans, vol. 2, 365-379. Manchester: St. Jerome Publishing.

Nida, E. 2004. Principles of correspondence. In The translation studies reader, ed. Lawrence Venuti, 153-167. London and New York: Routledge.

Ong, W. J. 1982. Orality and literacy. The technologizing of the word. New York: Routledge.

Petenova, Z. M. 1985. Yazyk i stil' russkikh bylin. L’vov: Vishcha shkola.

Putilov, B. N. 1997. Epicheskoe skazitel'stvo: tipologiya i etnicheskaya spetsifika. Moscow: Izdatel'skaya firma "Vostochnaya literatura" RAN.

Pym, A., and T. Horst. 2001. Translatability. In Routledge Encyclopedia of Translation Studies, ed. M. Baker, 273-277. London and New York: Routledge.

Rybnikov, P. N. 1861-67/1989-91. Pesni, sobrannye P. N. Rybnikovym. 3 vol. Petrozavodsk: Kareliya.

Saronne, E. T., and K. F. Danil'chenko. 1997. Giganti, incantatori e draghi. Milano: Luni editrice.

Tabakh'yan, P. V. 1980. Sopostavitel'naya stilistika russkogo i nemetskogo fol'klora. Kiev: Vishcha shkola.

Tedlock, D. 1972. On the translation of style in oral narrative. In Toward new perspectives in folklore, ed. A. Paredes, and R. Bauman, 114-133. Austin and London: University of Texas Press.

Tymoczko, M. 1995. The metonymics of translating marginalized texts. Comparative literature 47 (1): 11-24. http://www.jstor.org/stable/1771360.

1999. Translation in a postcolonial context: early Irish literature in English translation. Manchester : St. Jerome. 
Toury, G. 1995. Descriptive Translation studies and beyond. Amsterdam and Philadelphia: John Benjamins Publishing Company.

Ushakov, D. N. 1935-1940. Tolkovyy slovar' russkogo yazyka. Moscow: Ogiz.

Venuti, L. 2002. The translator's invisibility: a history of translation. London: Routledge.

Veselovskiy, A. N. 2008. Istoricheskaya poetika. 3rd ed. Moscow: LKI. 